\title{
Electro-organic synthesis of dibenzylaminodioxocyclohexa-dienecarboxylic acids
}

\author{
Davood Nematollahi ${ }^{a^{*}}$, Mehdi Hesari ${ }^{\mathrm{a}}$, and Sayed Saied Hosseiny Davarani ${ }^{\mathrm{b}}$ \\ ${ }^{a}$ Department of Chemistry, Faculty of Science, University of Bu-Ali-Sina, Hamadan - Iran \\ ${ }^{b}$ Department of Chemistry, Shahid Beheshti University, Tehran, Iran \\ E-mail:nemat@basu.ac.ir
}

\begin{abstract}
Electrochemical oxidation of dihydroxybenzoic acids 1a-c has been studied in the presence of dibenzylamine (3) as nucleophile in water/acetonitrile (90:10) solution using cyclic voltammetry and controlled-potential coulometry. The quinones 2a-c derived from dihydroxybenzoic acids participate in Michael addition reactions with dibenzylamine (3), and via ECE mechanism convert to the corresponding (dibenzylamino)dioxocyclohexadienecarboxylic acids 5a-c.
\end{abstract}

Keywords: Dihydroxybenzoic acid, electrooxidation, cyclic voltammetry, (dibenzylamino)dioxocyclohexadienecarboxylic acid

\section{Introduction}

Alkylaminoquinones are of considerable interest because they exhibit antitumor and antimalarial activities $^{1,2}$ and many of them are also involved in enzyme inhibition and DNA cross-linking. ${ }^{3}$ 1,2-Benzoquinone derivatives have been less extensively studied than the 1,4-benzoquinone derivatives because they are more difficult to prepare. ${ }^{2,4,5}$ The importance of amino derivatives of quinones has encouraged us to study ${ }^{6}$ and synthesize ${ }^{7}$ a number of these compounds. However, no report has been published so far about the chemical or electrochemical synthesis of (dibenzylamino)dioxocyclohexadienecarboxylic acids. Therefore, we have investigated the electro-oxidation of ortho and para dihydroxybenzoic acids in the presence of dibenzylamine as $\mathrm{N}$-nucleophile. The present work has led to the development of a facile and environmentally friendly electrochemical method for the synthesis of some new (dibenzylamino)dioxocyclohexadienecarboxylic acids in a two-compartment cell with high atom economy and good yields. 


\section{Results and Discussion}

\section{Electrochemical study of 2,3-dihydroxybenzoic acid (1a)}

Cyclic voltammograms of 2,3-dihydroxybenzoic acid (1a) in the absence and in the presence of dibenzylamine (3) in water/acetonitrile mixture (90:10, v/v) containing $0.2 \mathrm{M}$ phosphate buffer $(\mathrm{pH} 7.0)$ are shown in Figure 1. The cyclic voltammogram of 1a in the absence of dibenzylamine (3) (curve a) shows one anodic peak $\left(\mathrm{A}_{1}\right)$ at $0.28 \mathrm{~V}$ and the corresponding cathodic peak $\left(\mathrm{C}_{1}\right)$ at $0.22 \mathrm{~V}$, which correspond to the transformation of 2,3-dihydroxybenzoic acid (1a) to related $o$ benzoquinone (5,6-dioxocyclohexa-1,3-dienecarboxylic acid, 2a) and vice versa within a quasireversible two-electron process. ${ }^{8}$ At this condition, the peak-current ratio $\left(\mathrm{I}_{\mathrm{p}}^{\mathrm{Cl}} / \mathrm{I}_{\mathrm{p}}^{\mathrm{A1}}\right)$ is nearly unity; this can be considered as a criterion for the stability of $o$-benzoquinone 2a produced at the surface of the electrode under the experimental conditions. In other words, hydroxylation ${ }^{9}$ or dimerization ${ }^{10}$ reactions are too slow to be observed on the time scale of cyclic voltammetry.
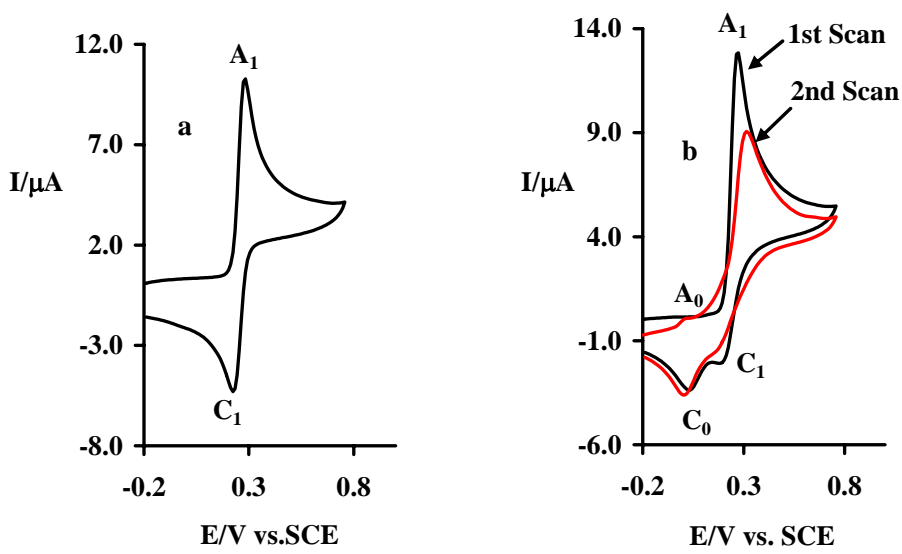

Figure 1. Cyclic voltammograms of (a) $1.0 \mathrm{mM}$ 2,3-dihydroxybenzoic acid (1a), (b) first and second cycles of $1.0 \mathrm{mM}$ 2,3-dihydroxybenzoic acid (1a) in the presence of $1.0 \mathrm{mM}$ dibenzylamine (3) at a glassy carbon electrode in water/acetonitrile (90:10) solution containing $0.2 \mathrm{M}$ phosphate buffer ( $\mathrm{pH} 7.0$ ). Scan rate: $50 \mathrm{mVs}^{-1} ; \mathrm{t}=25 \pm 1{ }^{\circ} \mathrm{C}$.

Figure 1 (curve b) shows the first cycle voltammogram obtained for a $1 \mathrm{mM}$ solution of $1 \mathrm{a}$ in the presence of $1 \mathrm{mM}$ dibenzylamine (3). The voltammogram exhibits two cathodic peaks $\mathrm{C}_{1}$ (0.18 V versus SCE (Saturated Calomel Electrode)) and $\mathrm{C}_{0}(0.03 \mathrm{~V}$ versus SCE). In the second cycle, a new peak $\left(\mathrm{A}_{0}\right)$ appears with an $\mathrm{E}_{\mathrm{p}}$ value of $0.01 \mathrm{~V}$ versus $\mathrm{SCE}$. This new peak is related to oxidation of intermediate $\mathbf{4 a}$.

Controlled-potential coulometry was performed in water/acetonitrile mixture $(90: 10, \mathrm{v} / \mathrm{v})$ (phosphate buffer, $\mathrm{c}=0.2 \mathrm{M}, \mathrm{pH}=7.0$ ) containing $0.30 \mathrm{mmol}$ of 2,3-dihydroxybenzoic acid (1a) and $0.30 \mathrm{mmol}$ of dibenzylamine (3) at peak $\mathrm{A}_{1}$ potential. Cyclic voltammetric analysis carried out during the electrolysis shows the progressive formation of new anodic peak $\left(\mathrm{A}_{0}\right)$, parallel to 
the disappearance of the $A_{1}$ peak (Figure 2). The anodic peak $\left(A_{1}\right)$ and cathodic peak $\left(C_{1}\right)$ disappear when the charge consumption becomes about $4 \mathrm{e}^{-}$per molecule of $\mathbf{1 a}$.

These observations are indicative of an ECE (Electron transfer-Chemical reactionElectron transfer) mechanism ${ }^{11}$ and allows to propose the pathway for the electro-oxidation of 2,3-dihydroxybenzoic acid (1a) in the presence of dibenzylamine (3) (Scheme 1). Accordingly, the 1,4-addition (Michael) reaction of dibenzylamine (3) to the o-benzoquinone derivative 2a leads to intermediate 4a. The oxidation of $\mathbf{4 a}$ is easier than the oxidation of $\mathbf{1 a}$ by virtue of the presence of more electron-donating groups. Since $\mathrm{E}_{1 / 2}^{\mathrm{A} 1 \text { and } \mathrm{C} 1}>\mathrm{E}_{1 / 2}^{\mathrm{A} 0 \text { and } \mathrm{C} 0}$, the occurrence of solution electron transfer (Scheme 2) is possible. So, we think that both mechanisms (ECE and Disp (disproportionation)) are participating in electrochemical oxidation of benzoic acid derivatives in the presence of dibenzylamine.
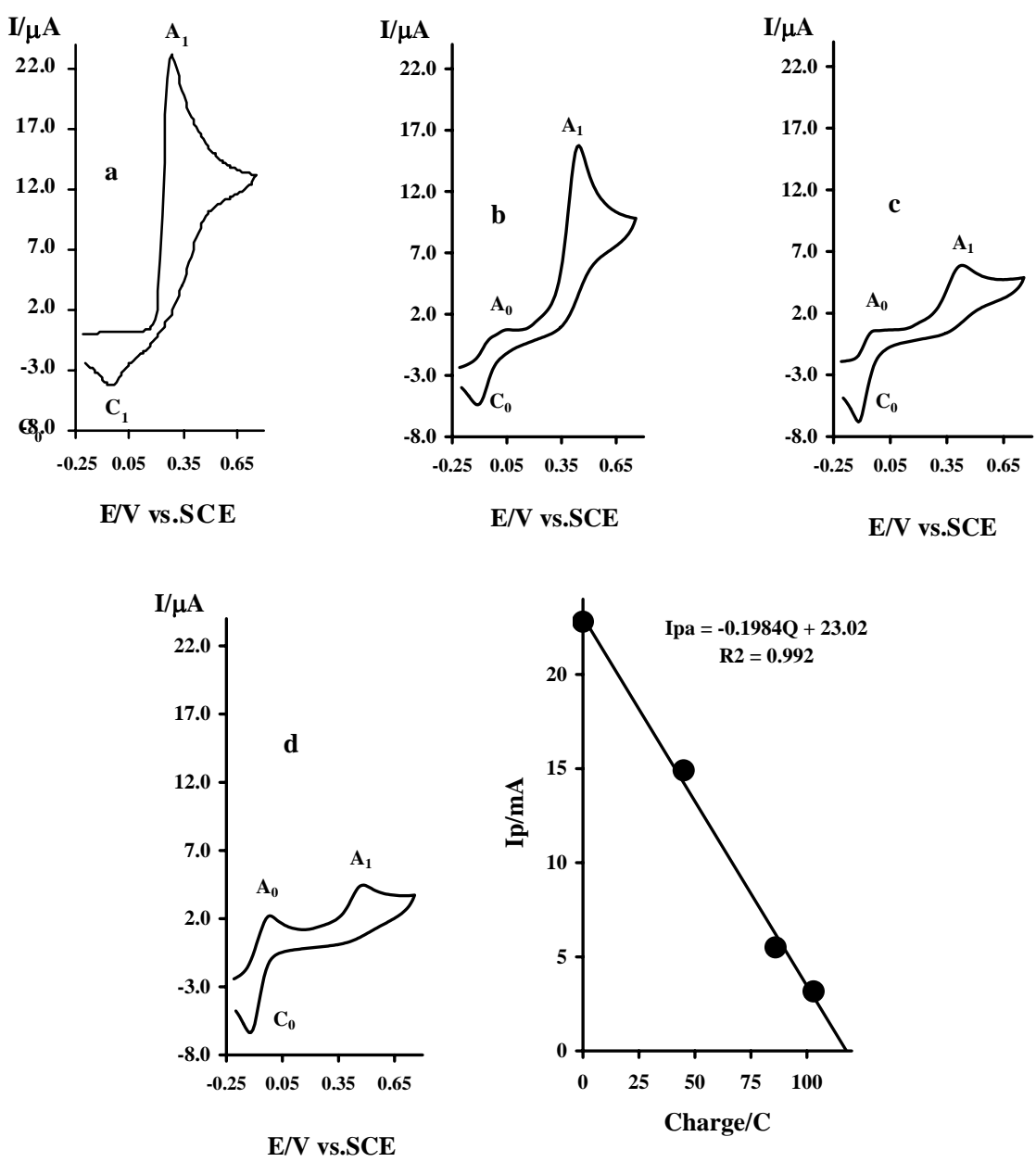

Figure 2. Cyclic voltammograms of $0.30 \mathrm{mmol} 2,3$-dihydroksybenzoic acid (1a) in the presence of $0.30 \mathrm{mmol}$ of dibenzylamine (3) in water/acetonitrile (90:10) mixture, containing $0.2 \mathrm{M}$ phosphate buffer ( $\mathrm{pH}$ 7.0) at a glassy carbon electrode during controlled-potential coulometry at $0.45 \mathrm{~V}$ vs. SCE. After consumption of (a) 0, (b) 45, (c) 86 and (d) 103 C. (e): variation of peak current $\left(\mathrm{Ipa}_{1}\right)$ vs. charge consumed. Scan rate $50 \mathrm{mVs}^{-1} ; \mathrm{t}=25 \pm 1^{\circ} \mathrm{C}$. 


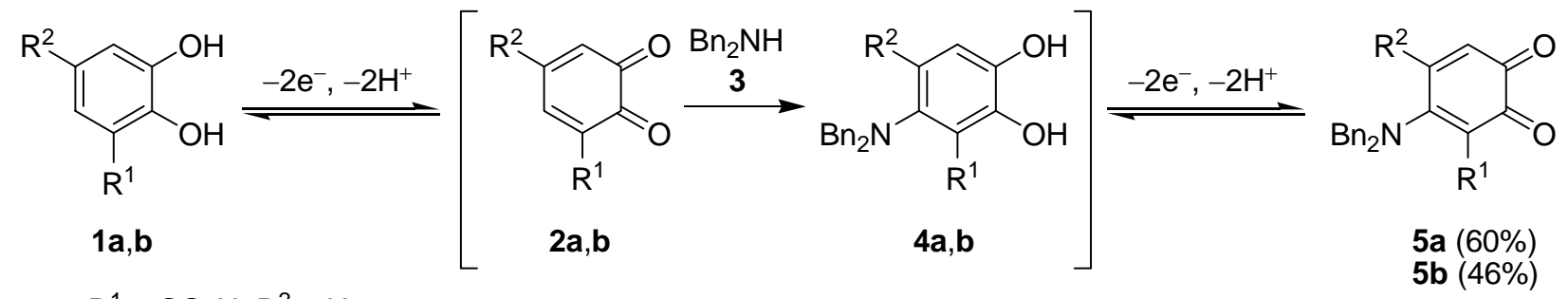

a: $\mathrm{R}^{1}=\mathrm{CO}_{2} \mathrm{H}, \mathrm{R}^{2}=\mathrm{H}$

b: $\mathrm{R}^{1}=\mathrm{H}, \mathrm{R}^{2}=\mathrm{CO}_{2} \mathrm{H}$

\section{Scheme 1}

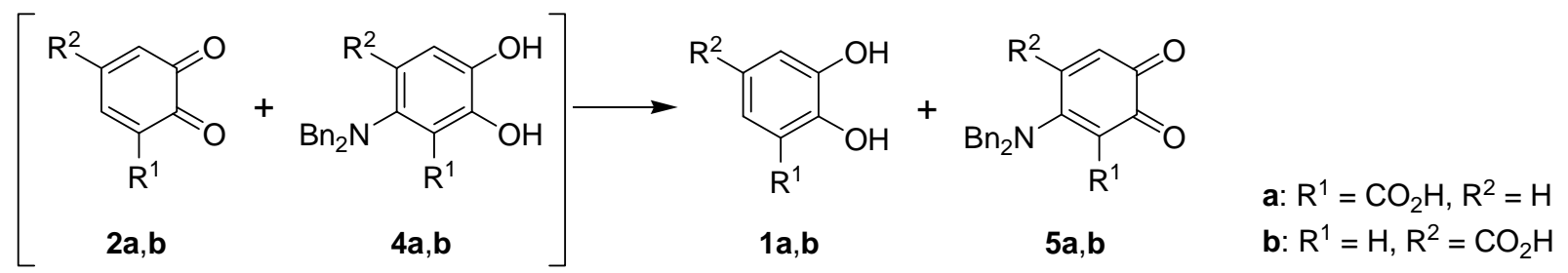

\section{Scheme 2}

The 1,4-addition (Michael) reaction of dibenzylamine (3) to the ortho-quinone intermediate 2a can conceivably occur at C-2 and C-3 resulting in products 5a or 6a, respectively (Figure 3). The ${ }^{1} \mathrm{H}$ NMR spectrum of the isolated product displays two doublet peaks with vicinal coupling constants $(\delta 6.50$ and 6.76$)$ in support of structure $5 a$.<smiles>O=C(O)C1=C(NCc2ccccc2)C=CC(=O)C1=O</smiles>

$5 a$<smiles>O=C(O)C1=CC(=NCc2ccccc2)C=C(C(=O)O)C1=O</smiles>

$6 a$

\section{Figure 3}

The electro-oxidation of 3,4-dihydroxybenzoic acid (1b) in the presence of dibenzylamine (3) in water/acetonitrile (90:10) solution in phosphate buffer ( $\mathrm{pH} 7.0,0.2 \mathrm{M}$ ) proceeds similarly (Scheme 1). Two ${ }^{1} \mathrm{H}$ NMR singlet peaks ( $\delta 5.40$ and 5.80) provide evidence of product structure $\mathbf{5 b}$ resulting from the 1,4-addition of dibenzylamine (3) at C- 6 of intermediate $4 \mathbf{b}$.

\section{Electrochemical study of 2,5-dihydroxybenzoic acid (1c)}

Under the same conditions the electrochemical oxidation of 2,5-dihydroxybenzoic acid (1c) in the presence of dibenzylamine (3) was performed using cyclic voltammetry. In comparison with the cyclic voltammogram of $1 \mathbf{a}$ the $p$-benzoquinone intermediate $2 \mathrm{c}$ formed by oxidation of $\mathbf{1 c}$ is 
less reactive toward the Michael addition reaction. A decreased peak current ratio $\left(\mathrm{I}_{\mathrm{p}}^{\mathrm{A} 1} / \mathrm{I}_{\mathrm{p}}^{\mathrm{C} 1}\right)$ shows this behavior. Time-dependent absorption spectra of the mixture of 2,5-dihydroxybenzoic acid (1c; $0.5 \mathrm{mM})$ and dibenzylamine $(3 ; 0.5 \mathrm{mM})$ were recorded during a controlled-potential coulometry at $0.20 \mathrm{~V}$ vs. SCE (Figure 4). In the course of the coulometry experiment an absorption peak at $\lambda_{\max } 534 \mathrm{~nm}$ keeps growing due to the formation of 2-dibenzylamino-3,6dioxocylohexa-1,4-dienecarboxylic acid (5c).

The electro-oxidation of 2,5-dihydroxybenzoic acid (1c) in the presence of dibenzylamine (3) (Scheme 3) is considered to involve the Michael acceptor 3,6-dioxocyclohexa-1,4-dienecarboxylic acid (2c) as an intermediate that could be attacked at positions C-2, C-4 or C-5 to yield 5c, 6c, 7c, respectively (Figure 5). The ${ }^{1} \mathrm{H}$ NMR spectrum of the isolated product exhibits two doublet peaks with vicinal coupling constants $(\delta 6.62$ and 7.02$)$ confirming structure $5 c$.

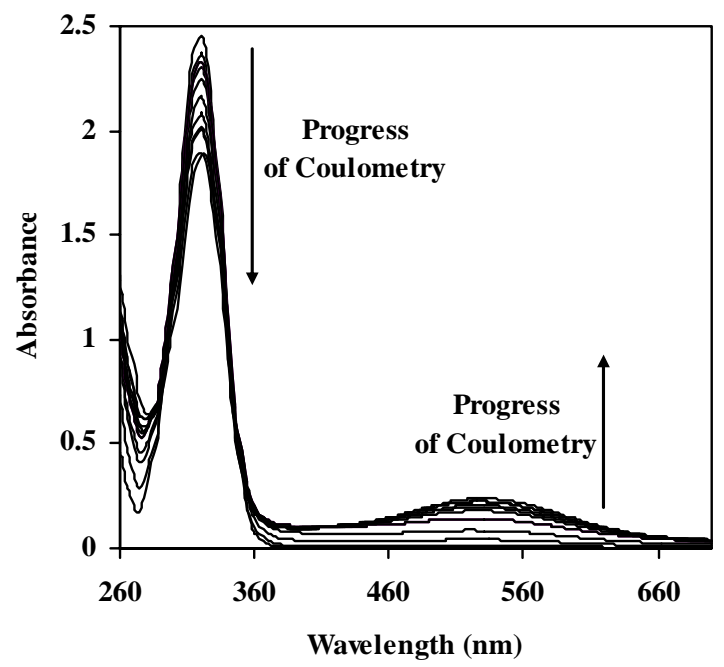

Figure 4. Absorption spectra of the mixture of 2,5-dihydroxybenzoic acid (1c) $(0.5 \mathrm{mM})$ and dibenzylamine (3) $(0.5 \mathrm{mM})$ during controlled-potential coulometry at $0.20 \mathrm{~V}$ vs. SCE in aqueous solution containing $0.2 \mathrm{M}$ phosphate buffer ( $\mathrm{pH} 7.0$ ).

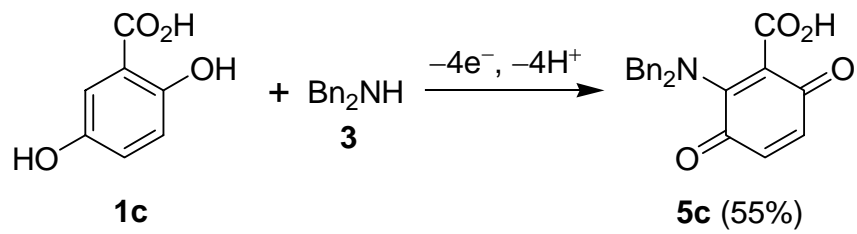

\section{Scheme 3}


<smiles>O=C(O)C1=C(NCc2ccccc2)C(=O)C=CC1=O</smiles>

5c<smiles>O=C(O)C1=CC(=O)C(C(=O)O)=CC1=O</smiles>

$6 \mathrm{c}$<smiles>CCCCCCCCCCCCCCCC(=O)O</smiles>

7c

\section{Figure 5}

The ${ }^{13} \mathrm{C}$ NMR spectra of $\mathbf{5 a}$ and $\mathbf{5 c}$, contrary to that of $\mathbf{5 b}$, show only one downfield peak at $\delta 172.8$ and 172.7, respectively. This can be related to the formation of intramolecular hydrogen bonds in 5a and 5c (Figure 6). ${ }^{12}$
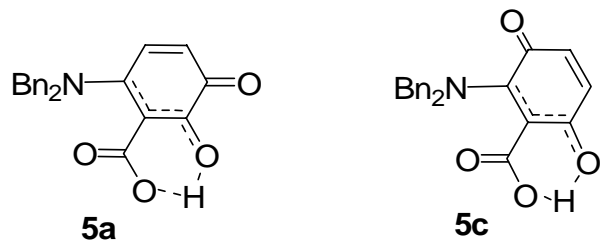

\section{Figure 6}

The mass spectra of compounds $5 \mathbf{a}-\mathbf{c}$ show strong protonated molecular ion peaks $[\mathrm{M}+2 \mathrm{H}]$ (and $[\mathrm{M}+3 \mathrm{H}]$ in $5 \mathbf{c}$ ) due to protonation of quinone, amino, and carbonyl groups. ${ }^{7,13}$

\section{Conclusions}

This work reports the electro-oxidation of dihydroxybenzoic acids (1) in water/acetonitrile solution to the corresponding quinones 2, which in turn, add dibenzylamine (3) to form (dibenzylamino)dioxocyclohexadienecarboxylic acids 5. The advantage of dibenzylamine (3) as a bulky nucleophile is the formation of monoamino-substituted benzoquinones as final products (Schemes 1 and 3). The present work has led to the development of a one-pot electrolytic method for the synthesis of new (dibenzylamino)dioxocyclohexadienecarboxylic acids 5a-c as final products, in good yields.

\section{Experimental Section}

General Procedures. Cyclic voltammetry, controlled-potential coulometry and preparative electrolysis were performed using an Autolab model PGSTAT 20 potentiostat/galvanostat. The working electrode used in the voltammetry experiment was a glassy carbon disc $(1.8 \mathrm{~mm}$ 
diameter) and a platinum wire was used as the counter electrode. The working electrode used in controlled-potential coulometry and macro-scale electrolysis was an assembly of four carbon rods (6 $\mathrm{mm}$ diameter and $4 \mathrm{~cm}$ length) and large platinum gauze constituted the counter electrode. In controlled-potential coulometry, the counter electrode compartment was separated from the working electrode with porous membrane electrode shape that involving counter electrode. The working electrode potentials were measured versus SCE (all electrodes were obtained from AZAR Electrodes). All experiment was carried out at a temperature of $25 \pm 1{ }^{\circ} \mathrm{C}$. Melting points of all synthesized compounds were determined in open capillary tubes and are uncorrected. IR spectra ( $\mathrm{KBr})$ were recorded on IFS66 Bruker FT-IR spectrometer. ${ }^{1} \mathrm{H}$ and ${ }^{13} \mathrm{C}$, NMR spectra (DMSO-d ( $_{6}$ were recorded on JEOL JNM-EX90A spectrometer operating at 90 and 22.6 MHz, respectively and BRUKER DRX-500 AVANCE spectrometer at 500.1 and 125.8, MHz, respectively. Mass spectra were recorded on a QP-1100EX Shimadzu Mass spectrometer operating at an ionization potential of $70 \mathrm{eV}$.

General procedure for the synthesis of (dibenzylamino)dioxocyclohexadienecarboxylic acids 5a-c. A solution of phosphate buffer (ca. $80 \mathrm{~mL}$; $=0.2 \mathrm{M}, \mathrm{pH}=7.0$ ) in water/acetonitrile (90:10; $80 \mathrm{~mL})$ solution containing dihydroxybenzoic acid (1a-c; $154.1 \mathrm{mg}, 1 \mathrm{mmol})$ and dibenzylamine (3; $197.3 \mathrm{mg}, 1 \mathrm{mmol}$ ) was electrolyzed in a two-compartment cell at $0.3 \mathrm{~V}$ vs. SCE. The electrolysis was terminated when the current decreased by more than $95 \%$. The process was interrupted during the electrolysis and the graphite anode was washed in acetone in order to reactivate it. After electrolysis, the precipitated solid was collected by filtration. The products were purified by column chromatography (silica gel; chloroform for 5a,b, chloroform/ether for 5c). After purification, the products were characterized by UV, IR, ${ }^{1} \mathrm{H}$ $\mathrm{NMR},{ }^{13} \mathrm{C}$ NMR and MS.

2-(Dibenzylamino)-5,6-dioxocylohexa-1,3-dienecarboxylic acid (5a). The product 5a was obtained as violet crystals, (208.4 mg, 60\% yield); mp 170-172 ${ }^{\circ} \mathrm{C}$. ${ }^{1} \mathrm{H}$ NMR (90 MHz, DMSO$\left.d_{6}\right): \delta 10.02$ (broad, 1H), 7.26-7.40 (m, 10H), $6.76(\mathrm{~d}, J=7.1,1 \mathrm{H}), 6.50(\mathrm{~d}, J=7.5,1 \mathrm{H}), 4.53(\mathrm{~s}$, $4 \mathrm{H}) .{ }^{13} \mathrm{C}$ NMR $\left(22.6 \mathrm{MHz}, \mathrm{DMSO}-d_{6}\right): \delta 172.8,150.6,145.8,131.7,130.5,129.8,128.5,120.3$, 117.36, 115.8, 110.7, 59.4. IR (KBr): $\widetilde{v} 3134,3034,2834,1601,1555,1500,1479,1456,1387$, $1319,1265,1190,1072,1017,977,844,752,696 \mathrm{~cm}^{-1}$. UV-Vis (acetonitrile, $\mathrm{c}=5 \times 10^{-4} \mathrm{~mol} \mathrm{dm}^{-}$ $\left.{ }^{3}\right): \lambda_{\max }(\varepsilon) 514,406 \mathrm{~nm}\left(576 \mathrm{~mol}^{-1} \mathrm{dm}^{3} \mathrm{~cm}^{-1}\right)$. EI-MS: $\mathrm{m} / \mathrm{z}(\%) 349$ (61) [M+2H], 313, 305(98), 258(12), 244(24), 228(46), 214(99), 196(25), 167(46), 152(47), 136(38), 109(41), 106(100), 91(90), 77(86), 65(84). Anal. Found. C 72.61; H 4.93; N 4.03. Calcd. For $\mathrm{C}_{21} \mathrm{H}_{17} \mathrm{NO}_{4} ; \mathrm{C} 72.60$; $\mathrm{H} 4.91 ; \mathrm{N} 4.05$.

6-(Dibenzylamino)-3,4-dioxocylohexa-1,5-dienecarboxylic acid (5b). The product 5b was obtained as red-orange crystals, (159.8 mg, 46\% yield); mp $165-167{ }^{\circ} \mathrm{C} .{ }^{1} \mathrm{H}$ NMR $(500.1 \mathrm{MHz}$, DMSO-d $\left.d_{6}\right): \delta 7.25-7.45(\mathrm{~m}, 10 \mathrm{H}), 5.80(\mathrm{~s}, 1 \mathrm{H}), 5.40(\mathrm{~s}, 1 \mathrm{H}), 4.77(\mathrm{~s}, 4 \mathrm{H}) .{ }^{13} \mathrm{C} \mathrm{NMR}(125.8 \mathrm{MHz}$, DMSO- $\left.d_{6}\right): \delta 181.1,176.9,164.0,154.6,136.9,129.0,127.5,127.0,104.5,104.2,57.0$. IR (KBr): $\widetilde{v} 3059,2986,2927,1668,1625,1545,1442,1359,1307,1262,1233,1183,1111,1027$, $945,905,802,730,697 \mathrm{~cm}^{-1}$. UV-Vis (acetonitrile, $\mathrm{c}=5 \times 10^{-4} \mathrm{~mol} \mathrm{dm}^{-3}$ ) $\lambda_{\max }(\varepsilon) 481,327 \mathrm{~nm}$ 
(451.6 mol $\mathrm{mm}^{-1} \mathrm{~cm}^{-1}$ ). EI-MS: m/z (\%) 349 (14) [M+2H], 256 (12), 228 (17), 91 (100). Anal. Found. C 72.61; H 4.93; N 4.03. Calcd. For $\mathrm{C}_{21} \mathrm{H}_{17} \mathrm{NO}_{4} ; \mathrm{C} 72.58 ; \mathrm{H} 4.89 ; \mathrm{N} 4.01$.

2-(Dibenzylamino)-3,6-dioxocylohexa-1,4-dienecarboxylic acid (5c). The product 5a was obtained as pink crystals, (191.1 mg, 55\% yield); mp 209-210 ${ }^{\circ} \mathrm{C} .{ }^{1} \mathrm{H}$ NMR $(90 \mathrm{MHz}$ DMSO$\left.d_{6}\right): \delta 10.01$ (broad, 1H), 7.20-7.49 (m, 10H), $7.02(\mathrm{~d}, J=8.5 \mathrm{~Hz}, 1 \mathrm{H}), 6.62(\mathrm{~d}, J=8.7 \mathrm{~Hz}, 1 \mathrm{H})$, $4.69(\mathrm{~s}, 4 \mathrm{H}) .{ }^{13} \mathrm{C}$ NMR $\left(22.6 \mathrm{MHz}, \mathrm{DMSO}-d_{6}\right): \delta 172.7,154.5,145.0,132.3,130.5,128.8,128.4$, 126.6, 122.2, 117.9, 110.8, 56.3. IR (KBr): $\widetilde{v} 3033,2977,1633,1589,1494,1458,1350,1293$, $1275,1226,1143,1081,1030,983,911,865,836,802,752,729,697,642,569 \mathrm{~cm}^{-1}$. UV-Vis (acetonitrile, $\left.\mathrm{c}=5 \times 10^{-4} \mathrm{~mol} \mathrm{dm}{ }^{-3}\right) \lambda_{\max }(\varepsilon) 456,334 \mathrm{~nm}\left(506.4 \mathrm{~mol}^{-1} \mathrm{dm}^{3} \mathrm{~cm}^{-1}\right)$. EI-MS: $\mathrm{m} / \mathrm{z}(\%)$ 350 (98) [M+3H], 332 (12), 258 (34), 240 (24), 91 (100), 65 (22). Anal. Found. C 72.61; H 4.93; $\mathrm{N}$ 4.03. Calcd. For $\mathrm{C}_{21} \mathrm{H}_{17} \mathrm{NO}_{4} ; \mathrm{C} 72.63 ; \mathrm{H} 4.90 ; \mathrm{N} 4.06$.

\section{References}

1. Lin, T. S.; Xu, S .P.; Zhu, L. Y.; Divo, A.; Sartorelli, A. J. Med. Chem. 1991, 34, 1634.

2. Huang, Z. D.; Chen, Y. N.; Menon, K.; Teicher, B. A. J. Med. Chem. 1993, 36, 1797.

3. Bittner, S.; Meenakshi, C.; Temtsin, G. Tetrahedron 2001, 57, 7423.

4. Kashima, C.; Tomotake, A.; Omote, Y. J. Org. Chem. 1987, 52, 6616.

5. Fischer, A.; Henderson, G. N. Synth. Commun. 1986, 641

6. Nematollahi, D.; Tammari, E.; Sharifi, S.; Kazemi, M. Electrochim. Acta 2004, 49, 591.

7. Nematollahi, D.; Hesari, M. J. Electroanal. Chem. 2005, 577, 197.

8. (a) Nematollahi, D.; Forooghi, Z. Electroanalysis 2003, 15, 1639. (b) Nematollahi, D.; Goodarzi, H. J. Org. Chem. 2002, 67, 5036.

9. (a) Papouchado, L.; Petrie, G.; Adams, R. N. J. Electroanal. Chem. 1972, 38, 389. (b) Papouchado, L.; Petrie, G.; Sharp, J. H.; Adams, R. N. J. Am. Chem. Soc. 1968, 90, 5620. (c) Young, T. E.; Griswold, J. R.; Hulbert, M. H. J. Org. Chem. 1974, 39, 1980.

10. (a) Rayn, M. D.; Yueh, A.; Wen-Yu, C. J. Electrochem. Soc. 1980, 127, 1489. (b) Nematollahi, D.; Rafiee, M.; Samadi-Maybodi, A. Electrochimica Acta 2004, 49, 2495.

11. Bard, A. J.; Faulkner, L. R. Electrochemical Methods. 2001, $2^{\text {nd }}$ Edn., Wiley: New York, p 512. (b) Greef, R.; Peat, R.; Peter, L. M.; Pletcher D.; Robinson, J. Instrumental Methods in Electrochemistry, 1990, Ellis Horwood Limited: New York, p 60.

12. Hatzipanayioti, D.; Karaliota, A.; Kamariotaki, M.; Veneris, A. Transition Met. Chem. 1998, 23, 407.

13. (a) Bittner, S.; Meenakshi, C.; Temtsin, G. Tetrahedron 2001, 57, 7423. (b) Pachatouridisa, C.; Couladourosb, E. A.; Papageorgioua, V. P.; Liakopoulou-Kyriakidesa, M. Letters in Peptide Science 1998, 5, 259. 